\title{
Review Article \\ Filter Cake and Vinasse as Fertilizers Contributing to Conservation Agriculture
}

\author{
Renato de Mello Prado, Gustavo Caione, and Cid Naudi Silva Campos \\ Department of Soils and Fertilizers, Universidade Estadual Paulista "Júlio de Mesquita Filho", \\ Via de Acesso Paulo Donato Castellane s/n, 14884-900 Jaboticabal, SP, Brazil \\ Correspondence should be addressed to Renato de Mello Prado; rmprado@fcav.unesp.br
}

Received 9 April 2013; Revised 3 June 2013; Accepted 11 July 2013

Academic Editor: Philip J. White

Copyright (C) 2013 Renato de Mello Prado et al. This is an open access article distributed under the Creative Commons Attribution License, which permits unrestricted use, distribution, and reproduction in any medium, provided the original work is properly cited.

\begin{abstract}
Utilising organic residues in agriculture contributes to the conservation of natural resources by recycling carbon and mineral elements. Organic residues produced by the sugar and alcohol agroindustries have great potential for use in conservation agriculture. The production of sugar and alcohol generates large quantities of byproducts, such as filter cake and vinasse, which can be used as soil improvers and substitutes for inorganic phosphorus and potassium fertilizers. However, the use of these residues in agriculture requires specific recommendations for each pedoclimatic condition to prevent environmental damage.
\end{abstract}

\section{Introduction}

Recently, the high cost of fertilizers and concerns about environmental protection have been great incentives to study the recycling of the large quantities of organic residues produced as byproducts of the sugar and alcohol agroindustries in agriculture.

The mechanized harvest of sugar cane, which is used widely in countries producing this crop, leaves about 6$24 \mathrm{tha}^{-1}$ of residues on the soil surface [1]. The layer of residues protects the soil against erosion, inhibits weed germination, improves water retention, ameliorates physical and biological soil properties, and is a source of plant nutrients. In addition, industrial processing of sugar cane to produce sugar and alcohol also generates residues, such as filter cake and vinasse, which have a great potential for use in agriculture as soil improvers and fertilizers. Commercial uses of industrial residues strengthen the sugar and alcohol agroindustries [2].

Filter cake, a residue from the treatment of sugar cane juice by filtration, is a rich source of phosphorus and organic matter and has a large moisture content. It has been used as a complete or partial substitute for mineral fertilizers in sugar cane cultivation $[3,4]$, in the cultivation of other crops [510], in composting [11], in vermicomposting [12], and as a substrate in the production of seedlings $[13,14]$.
Vinasse is an aqueous effluent of the distillation unit in the sugar-alcohol industry and a problem to the sector due to the large quantities produced and its potential effects as an environmental pollutant. It is largely composed of water, organic matter, and mineral elements. The environmental damage caused by discarding vinasse into the soil or running waters was an incentive to studies aiming to find alternative, economic applications for this residue. Results from such studies indicate that, properly used, vinasse contributes to improvements in soil quality [15-25] and agricultural productivity $[19,24-30]$.

Recycling organic residues is a sustainable activity, which is increasingly necessary when dealing with natural resources [31]. It is recognized that the use of filter cake and vinasse, which are low cost materials, can improve soil fertility. Some authors even suggest that their use is beneficial to soil physical attributes, such as stability and average weighted diameter of aggregates [32]. It is possible to estimate the potential contribution of byproducts produced by the sugar-alcohol agroindustry to the annual recycling of nitrogen, phosphorus, and potassium in cultivated land with sugar cane in Brazil (Table 1). These amount to $293 \mathrm{kt} \mathrm{N}, 99.6 \mathrm{kt} \mathrm{P}_{2} \mathrm{O}_{5}$, and 197 kt $\mathrm{K}_{2} \mathrm{O}$. It should be noted that nitrogen and phosphorus are present as organic compounds and must be mineralized before becoming readily available to plants [33]. 
TABLE 1: Estimates of the potential contribution of byproducts produced by the sugar-alcohol agroindustry to the annual recycling of mineral elements in agriculture (adapted from [33]).

\begin{tabular}{|c|c|c|c|c|c|c|c|}
\hline \multirow[b]{2}{*}{ Residues } & \multicolumn{3}{|c|}{ Nutrients } & \multirow[b]{2}{*}{ Volume of residues } & \multicolumn{3}{|c|}{ Returning nutrients } \\
\hline & $\mathrm{N}$ & $\begin{array}{r}\mathrm{P}_{2} \mathrm{O}_{5} \\
\text { (\% in dry } \mathrm{r}\end{array}$ & $\mathrm{K}_{2} \mathrm{O}$ & & $\mathrm{N}$ & $\left(\mathrm{tyr}^{-1}\right)$ & $\mathrm{K}_{2} \mathrm{O}$ \\
\hline Filter cake $^{1}$ & 1.40 & 1.94 & 0.39 & 2.34 million $\mathrm{t}$ dry cake $\mathrm{yr}^{-1}$ (Mt dwt) & 32800 & 45400 & 9130 \\
\hline Straw $^{2}$ & 0.46 & 0.11 & 0.57 & 34.5 million $\mathrm{t}$ dry straw $\mathrm{yr}^{-1}$ & 158700 & 37950 & 196650 \\
\hline \multicolumn{8}{|c|}{$\left(\mathrm{g} \mathrm{m}^{-3}\right.$ vinasse $)$} \\
\hline Vinasse $^{3}$ & 375 & 60 & 2.035 & 270 billion $\mathrm{L} \mathrm{yr}^{-1}$ & 101250 & 16200 & 549450 \\
\hline Total & - & - & - & - & 292750 & 99550 & 755230 \\
\hline
\end{tabular}

${ }^{1}$ Supposing that the cultivated area in Brazil is 6.9 million hectares and 475 million tons of cane sugar are harvested, of which 223 million tons are utilized for sugar production generating $35 \mathrm{~kg}$ of filter cake ton ${ }^{-1}$ of crushed cane; filter cake with $70 \%$ moisture content. ${ }^{2}$ Generation of $5 \mathrm{t} \mathrm{ha}^{-1}$ of dry straw, considering that $100 \%$ of the sugar cane cultured area in Brazil is not burnt. ${ }^{3}$ Alcohol production: 20.8 billion liters; vinasse generation: $13 \mathrm{~L} \mathrm{~L}{ }^{-1}$ of produced alcohol.

The objective of this review is to evaluate the potential for the agricultural use of filter cake and vinasse and to discuss not only recent advances but also the necessity for further research.

\section{Filter Cake}

Filter cake is utilized as fertilizer in several countries, including Brazil, India, Australia, Cuba, Pakistan, Taiwan, South Africa, and Argentina. The residue is produced in large volumes $\left(30-40 \mathrm{~kg} \mathrm{t}^{-1}\right.$ of crushed cane) and it contains a considerable amount of organic matter and mineral elements required for plant nutrition, characteristics that explain its potential for agriculture. It can partially substitute for mineral fertilizers [4], and some suggestions have been made as to the amounts to be applied in the cultivation of sugar cane. In Brazil, the recommended applications of filter cake preplanting are $80-100 \mathrm{tha}^{-1}$ if applied to the whole area, 15$30 \mathrm{tha}^{-1}$ if applied in the planting grooves, or $40-50 \mathrm{tha}^{-1}$ if applied between the grooves [34].

The chemical composition of filter cake is a function of the variety and maturation of the sugar cane, type of soil, procedure of juice clarification, and various other factors. Table 2 shows chemical composition data from various reports. Of the mineral constituents of filter cake, phosphorus is the most significant as a fertilizer in agriculture and, for this reason, it is intensely studied. Phosphorus is the nutrient mostly commonly applied to tropical soils due to its low natural availability, its high capacity for adsorption to soil colloids, and its joint precipitation with iron and aluminum oxides and hydroxides [35].

The main effects of filter cake on soil chemical properties are increased nitrogen, phosphorus, and calcium concentrations, increased cation exchange capacity (CEC), and reduced concentrations of exchangeable aluminum $\left(\mathrm{Al}^{3+}\right)$, which is toxic to plants [37]. Beneficial effects on physical and biological soil properties are also observed. Thus, due to its characteristics, filter cake can play a fundamental role in agricultural production, in the maintenance of soil fertility, and as a soil conditioner [33].
TABLE 2: Concentrations of organic matter (OM) and mineral elements, $\mathrm{pH}$ values, and $\mathrm{C} / \mathrm{N}$ ratios determined in filter cake calculated on dry weight basis. Data are taken from reports of different authors for contrasting pedoclimatic conditions.

\begin{tabular}{lccccc}
\hline \multirow{2}{*}{ Determinations } & \multicolumn{5}{c}{ Filter cake } \\
& $(*)$ & {$[10]$} & {$[12]$} & {$[36]$} & Average \\
\hline $\mathrm{OM}(\%)$ & 29.6 & 15 & - & - & 22.3 \\
$\mathrm{pH}$ & 8.2 & - & 7.1 & - & 7.7 \\
$\mathrm{~N}(\%)$ & 1.4 & 4.8 & 1.6 & 0.3 & 2.0 \\
$\mathrm{P}(\%)$ & 1.2 & 1.8 & 1.3 & 0.1 & 1.1 \\
$\mathrm{~K}(\%)$ & 0.2 & 0.3 & 0.4 & 0.4 & 0.3 \\
$\mathrm{Ca}(\%)$ & 2.7 & 1.6 & 2.5 & 1.7 & 2.1 \\
$\mathrm{Mg}(\%)$ & 1.1 & 0.4 & - & 0.2 & 0.6 \\
$\mathrm{~S}(\%)$ & 0.2 & 0.3 & - & - & 0.25 \\
$\mathrm{C} / \mathrm{N}$ ratio & 12 & - & 25 & 36 & 24 \\
\hline
\end{tabular}

*: Data of the authors. - : Not determined.

\section{Effects of Filter Cake Application on the Production and Quality of Various Crops}

A report from Egypt [7] showed that the use of filter cake, enriched by rock phosphate in the presence or absence of a biofertilizer, in organic onion culture resulted in improved plant nutrition, growth and crop production, in addition to better export quality.

The productivity of sugar cane crops receiving organic and mineral fertilizers was analyzed in a study conducted in Cuba [38]. It was observed that soil structure was improved when natural and organic fertilizers were used rather than chemical fertilizers. The authors reported that application of $15 \mathrm{t} \mathrm{ha}^{-1}$ of filter cake plus $2 \mathrm{tha}^{-1}$ zeolite, $4 \mathrm{tha}^{-1}$ of compost and $2 \mathrm{tha}^{-1}$ of phosphate and calcareous rock had better residual effects on soil properties that were reflected in the agricultural and industrial yield of sugar cane for over three years.

In Swaziland, the destination of filter cake is a problem to the country. It is not widely used as a fertilizer, but one report [6] considers that this organic product should be better studied and used, for example, in the cultivation of 
manioc, in a similar manner to maize [39] and sweet potato cultivation [5]. There are indications that addition of filter cake at $60 \mathrm{tha}^{-1}$ has potential as an organic amendment in manioc production by preventing competition with weeds and increasing productivity by $50 \%$ compared to mineral fertilization [6].

Another study in Swaziland [8] reports that the use of filter cake application is of great importance due to limited funds to buy chemical fertilizers in addition to its environmental benefits. The authors studied the application of different amounts of filter cake in maize cultivation $(0$, 10, 20, $40 \mathrm{tha}^{-1}$ ) and reported that the higher applications increased soil organic matter. Soil phosphorus concentrations increased from $6 \mathrm{mg} \mathrm{kg}^{-1}$ (without fertilizer) to $56 \mathrm{mg} \mathrm{kg}^{-1}$, while treatments with mineral fertilizer led to a phosphorus concentration of only $24 \mathrm{mg} \mathrm{kg}^{-1}$. Micronutrient concentrations were also increased, with exception of boron and copper. Maize yields were also increased by the addition of filter cake. Yields of maize crops receiving the largest amounts of filter cake $\left(5,254 \mathrm{~kg} \mathrm{ha}^{-1}\right)$ were comparable to those receiving chemical fertilizers $\left(5,046 \mathrm{~kg} \mathrm{ha}^{-1}\right)$, and both were much larger than the control treatment $\left(3,732 \mathrm{~kg} \mathrm{ha}^{-1}\right)$.

In a study conducted in Indonesia [9], ashes of rice husks and filter cake were applied at two amounts to cabbages and phosphorus availability in soil, phosphorus uptake by plants, and plant growth were determined. The results indicated that phosphorus availability increased $120 \%$ and $78 \%$, when rice husk ashes and filter cake were applied, respectively. The treatments increased silicon concentrations, cation exchange capacity, solution $\mathrm{pH}$, and anion concentrations in the soil. The authors also observed that in soils containing high amounts of organic matter, addition of rice ashes and filter cake increased phosphorus uptake 3-fold and 2-fold and increased plant growth by $197 \%$ and $231 \%$, respectively. In soils poor in organic matter addition of rice ashes and filter cake increased phosphorus uptake by 1.9-fold and 2.7-fold and increased plant growth by $17 \%$ and $11.9 \%$, respectively, compared to untreated soils.

In a report from India [40] the combined application of $\mathrm{N}$ $\left(0,75,100\right.$, and $\left.150 \mathrm{~kg} \mathrm{ha}^{-1}\right)$ and filter cake $\left(0,10,20,30 \mathrm{tha}^{-1}\right.$, with $80 \%$ water content) to sugar cane indicated that $10 \mathrm{tha}^{-1}$ of filter cake together with $75 \mathrm{~kg} \mathrm{ha}^{-1} \mathrm{~N}$ produced equivalent yields to $150 \mathrm{~kg} \mathrm{ha}^{-1} \mathrm{~N}$, resulting in the saving of $75 \mathrm{~kg} \mathrm{ha}^{-1}$ of chemical $\mathrm{N}$ fertilizer.

Assays conducted in a Vertisoil in Sudan [41] indicated that filter cake applications to crops increased soil concentrations of organic matter, organic carbon, total nitrogen, and available phosphorus.

Studies conducted in Brazil [42] evaluated the effects of filter cake in combination with mineral fertilizers $(0,50$, and $100 \%$ of the recommended dose) in sugar cane production. It was observed that filter cake improved soil fertility, expressed as increased concentrations of macro- and micronutrients, and reduced soil acidity and concentrations of soil aluminum. Sugar cane plants showed a positive response to the addition of filter cake through increased concentrations of phosphorus, potassium, and copper in the aerial parts. The authors concluded that the use of filter cake in combination with mineral fertilizers can maximize productivity and reduce the costs associated with mineral fertilizers.

In another Brazilian experiment [4], the response of vegetative growth and productivity of sugar cane to the application of fertilizers containing filter cake enriched with soluble phosphate was studied. It was verified that phosphorus increased productivity in sugar cane and that the application of filter cake to the planting grooves could substitute for part of the inorganic phosphate fertilizer. The best combination suggested by the authors to optimize the concentration of soluble solids and sugar production was $2.6-2.7 \mathrm{t} \mathrm{ha}^{-1}$ of filter cake in combination with $160-190 \mathrm{~kg} \mathrm{ha}^{-1}$ of $\mathrm{P}_{2} \mathrm{O}_{5}$.

The yield of lettuce in Brazil [10] showed a linear increase with the application of filter cake from 0 up to $40 \mathrm{tha}^{-1}$.

The beneficial effects of filter cake were also demonstrated in Brazil [3] in a field study of ratoon cane where the application of $70 \mathrm{tha}^{-1}$ of fresh filter cake increased the production of cane sugar internodes.

\section{Other Applications of Filter Cake in Agriculture (Composting, Vermicomposting, and Substrate)}

Some factors, such as lack of solubility and unbalanced concentrations of nutrients, limit the application of filter cake to soil [12]. The strong disagreeable smell during biological degradation [43], the high temperature of the residue $\left(65^{\circ} \mathrm{C}\right)$, and the long period of natural decomposition [44] are additional disadvantages. Reports in the literature mention immobilization of nutrients and phytotoxicity after application of residues that are not composted or otherwise stabilized [45]. Discarding the raw residue is of concern in developing countries, as for example, in India [12].

Vermicomposting is an important technique for the utilization of filter cake. Filter cake has a high potential [12] as a starting material for vermicomposting and results in a biologically stable product that is free of pathogens, as confirmed by coliform counting. In India [46], vermicomposting of filter cake in combination with equine manure accelerated mineralization of nutrients and was adequate for growth and reproduction of earthworms.

Other authors suggest composting as a viable use of filter cake [11]. In countries like Thailand, enhanced performance at composting facilities for organic products needs improvements to preserve nitrogen concentration and produce a stable product in the short term. The $\mathrm{C} / \mathrm{N}$ ratio in filter cake is around 14 and in sugar cane bagasse, another sugar cane residue, it is 100 . Therefore, the filter cake composting could result in considerable ammonia $\mathrm{N}$ loss through volatilization due to the low $\mathrm{C} / \mathrm{N}$ ratio. On the other hand, bagasse composting is only possible with the addition of $\mathrm{N}$ due, in this case, to the high $\mathrm{C} / \mathrm{N}$ ratio. Since composting maturation is highly dependent on the nature of organic residues, investigators in Thailand [11] determined the time required for filter cake to compost to a stable product and considered that composting a mixture of bagasse and filter cake $(2: 1$ by weight) would prevent $\mathrm{N}$ losses by increasing the $\mathrm{C} / \mathrm{N}$ ratio. The authors concluded that nitrogen loss was 
TABLE 3: The chemical requirements for oxygen (CRO), biological requirements for oxygen (BRO), electrical conductivity (EC), total dissolved solids (TDS), $\mathrm{pH}$ values, sodium and macronutrient concentrations of vinasse according to reports of various authors.

\begin{tabular}{lccccc}
\hline Determinations & \multicolumn{5}{c}{ Vinasse } \\
& $(*)$ & $(51)$ & $(17)$ & $(15)$ & Average \\
\hline $\mathrm{CRO}\left(\mathrm{mg} \mathrm{L}^{-1}\right)$ & 21.450 & 26.771 & 48.860 & - & 32.360 \\
$\mathrm{BRO}\left(\mathrm{mg} \mathrm{L}^{-1}\right)$ & 10.000 & 5.000 & 21.275 & - & 12.092 \\
$\mathrm{EC}\left(\mathrm{dS} \mathrm{m}^{-1}\right)$ & 14.12 & 11.5 & 9.65 & 3.6 & 9.72 \\
$\mathrm{TDS}\left(\mathrm{mg} \mathrm{L}^{-1}\right)$ & 7.940 & 11.352 & 19.000 & - & 12.764 \\
$\mathrm{pH}$ & 4.5 & 4.4 & 4.6 & 5.7 & 4.8 \\
$\mathrm{~N}\left(\mathrm{mg} \mathrm{L}^{-1}\right)$ & 410 & - & - & 560 & 485 \\
$\mathrm{P}\left(\mathrm{mg} \mathrm{L}^{-1}\right)$ & 160 & - & 175 & 190 & 175 \\
$\mathrm{~K}\left(\mathrm{mg} \mathrm{L}^{-1}\right)$ & 3.100 & 1.123 & 1.392 & 960 & 1.644 \\
$\mathrm{Na}\left(\mathrm{mg} \mathrm{L}^{-1}\right)$ & 350 & 113 & 110 & - & 191 \\
$\mathrm{Ca}\left(\mathrm{mg} \mathrm{L}^{-1}\right)$ & 640 & 352 & 728 & 280 & 500 \\
$\mathrm{Mg}\left(\mathrm{mg} \mathrm{L}^{-1}\right)$ & 340 & 16 & 29 & 130 & 129 \\
\hline
\end{tabular}

*: Data of the authors. - : Not determined.

reduced by $12-15 \%$ and that both products have potential use in agricultural production. They also observed that during the first five days of composting the temperature of the mixture rose to about $55^{\circ} \mathrm{C}$ but decreased considerably $\left(<40^{\circ} \mathrm{C}\right)$ in the next 15-20 days. The time for complete composting took approximately 90 days.

Another application for filter cake is as a substrate for seedling production. Some trials conducted in Brazil have indicated that filter cake mixed with bagasse could be an adequate substrate for the production of eucalyptus [47] and citrus seedlings [14]. Citrus plants cultivated in this substrate were ready for grafting 120 days after transplanting, whilst plants growing in commercial substrate were not ready at this time. The addition of $18 \mathrm{~g} \mathrm{k}^{-1} \mathrm{~N}$ to plants growing in substrate containing filter cake resulted in taller plants with more leaves, greater leaf area, and larger aerial dry matter than plants grown in commercial substrate [14].

Evaluation of different substrates in the production of vegetable seedlings [13] verified that composted filter cake enriched with $4 \mathrm{~kg} \mathrm{~m}^{-3}$ of plain superphosphate produced better plant responses than commercial substrates.

\section{Vinasse}

Alcohol production generates large quantities of agroindustrial residues, the main one being vinasse, an aqueous effluent of the distillation unit in the sugar-alcohol industry [29]. The effluent is troublesome for the sector, not only because large volumes are produced but mainly because it can contribute to pollution.

The quantity of vinasse produced depends on the processing technique employed and also on the wine composition, varying between 10 and 18 liters of vinasse per liter of alcohol produced [48]. It originates from three sugary musts: molasses, mixed must, and juice. Vinasse in natura is a dilute solution and its application to soil is made in high quantities, making use difficult in areas distant from the sites of production. However, vinasse can be concentrated by evaporation, resulting in a product with higher economic viability that can be transported to distant locations.

Organic matter, $\mathrm{K}, \mathrm{N}, \mathrm{Ca}$, and $\mathrm{Mg}$ are the main chemical components of vinasse (Table 3 ), $\mathrm{K}$ being the most important mineral element for the agricultural use of the residue. Therefore, vinasse is a source of nutrients, organic matter, and water and its use can contribute to increased productivity of sugar cane [29], with effects on the chemical [15], physical [20], and biological [49] soil attributes.

However, the amount of vinasse applied in agriculture must follow appropriate guidelines, which vary according to soil characteristics. Specific recommendations must be followed for each region to prevent excessive use and consequent mineral lixiviation, for example, of nitrate and potassium, and contamination of subterranean waters. Also, the high content of organic matter in vinasse can contribute to significant pollution.

\section{Vinasse as a Pollutant}

The use of vinasse in agriculture is an important conservation practice, but its use has been challenged due to its high polluting potential to both soil and subterranean waters [48].

Characteristics of vinasse that contribute to pollution are high CRO (chemical requirements for oxygen) and BRO (biological requirements for oxygen) values, an acidic $\mathrm{pH}$, the elevated temperatures during production, and the consequent corrosive power [49]. Continuous application of high volumes of vinasse leads to increased soil nitrogen and potassium, the main chemical components of this residue [50, 51]. Vinasse also promotes soil alterations, such as improved aggregation, but this culminates in higher water infiltration, lixiviation of mineral elements, and contamination of subterranean waters.

Studies conducted in Mexico [52] studied the influence of the raw material and anaerobically-aerobically treated vinasse (a treatment conducted in the presence and absence of oxygen to remove dissolved organic matter) on soil chemical properties. The authors concluded that untreated vinasse posed a risk of soil salinization and contamination by zinc and manganese. A report from Colombia [53] compared the physicochemical properties of vinasse residues for sugar cane processing with synthetic substrates. The results indicated that the use of both residues affected water quality and had environmental impacts. The authors suggested that the impacts of vinasse could be reduced by biological treatments, such as aerobic and anaerobic technologies that removed organic matter, nitrates, and dissolved solids.

Analysis of ground water quality in areas of sugar cane production fertigated with in natura vinasse in volumes of $300 \mathrm{~m}^{3} \mathrm{ha}^{-1}$ soil [50] concluded that the practice minimizes the polluting potential of the residue but still affected the quality of ground water, irrespective of the soil type.

Another report from Brazil [54] relates studies on the effects of vinasse $\left(300 \mathrm{~m}^{3} \mathrm{ha}^{-1}\right)$ on properties of various soils, 
including weakly humic Gley and Cambisol, conducted over 10 years. The authors concluded that the amounts of heavy metals were not changed and there was little risk of soil contamination with these elements.

The effect of in natura vinasse applied at 0,350 , and $700 \mathrm{~m}^{3} \mathrm{ha}^{-1}$ on the leaching of mineral elements was studied in three soils [51]. It was shown that cation concentrations in the leachate were less than those in the vinasse, indicating the high cation retention of soils. In a complementary study [55] the physicochemical properties of percolates in soils, which received vinasse applications of 0,350 , and $700 \mathrm{~m}^{3} \mathrm{ha}^{-1}$ for different lengths of time (30 and 60 days), were evaluated and the parameters analyzed (CRO, BRO, EC, TDS, and $\mathrm{pH}$ ) indicated lack of environmental problems and that the risk of polluting subterranean waters was low.

It is obvious that there is no consensus about the polluting capacity of vinasse. The two main lines of thought indicate, on one side, deleterious effects on ground and surface waters while the other side claims that rational use of the residue does not result in environmental risk. However, it should be emphasized that depending on the amount of vinasse applied it might act as a pollutant or a beneficial soil conditioner. In this context, a review article [48] concludes that a consensus among authors is that the appropriate application of vinasse must consider the soil chemical and physical characteristics, besides aspects like the history of residue application, the intensity of cultivation in the agricultural area, and the proximity of water springs.

\section{Effects of Vinasse on the Improvement of Soil Quality}

Vinasse is being utilized in irrigation, mainly in sugar cane culture with results indicating improved quality in soil chemical, physical, and biological properties. In Brazil, several studies show the beneficial effects of the use of vinasse on soil chemical and physical properties. Increased concentrations of $\mathrm{K}, \mathrm{Ca}$, and $\mathrm{Mg}$, improved soil macroaggregation, and a better development of the radicular system in sugar cane have all been observed following the application of vinasse [15]. The use of vinasse in fertigation increased cation concentrations in the soil, especially potassium [16]. In this context, the effects of application of vinasse to sugar cane in Brazil were evaluated over 10 years [17]. It was concluded that macronutrients were more abundant in the soil profile, but micronutrient availability was reduced.

In a comparative study of different soil types before and after application of vinasse [18], it was observed that the residue increased the $\mathrm{pH}$ and potassium concentrations in depths varying according to the type of soil. Another group of investigators [19] also verified increased potassium and organic carbon concentrations when studying the chemical properties of soils treated with vinasse and used for sugar cane production. Therefore, if vinasse is an important source of potassium, its use could reduce the need for inorganic potassium fertilizers.

The effects on soil physicochemical properties after continuous application of vinasse for three years were analyzed in a study conducted in China [20]. The results showed a decrease in soil density, increased capillary porosity and, again, increased concentrations of potassium. It was concluded that continuous application of the residue promotes conditions able to sustain the growth and productivity of sugar cane. Another report from the same country [21] concluded that vinasse used as a fertilizer increases soil fertility in sugar cane production systems.

The populations of microorganisms, bacteria in general, and actinomycetes, in soil cultured with sugar cane fertilized with different organic residues [22] were larger when soils were treated with vinasse and filter cake compared to other residues, implying an improvement in the biological quality of soil when these residues are used.

The beneficial effects and risks of applying vinasse from wine production to the soil over extended periods have been studied in Spain [23]. The treatment resulted in increased soil electrical conductivity and a small decrease in $\mathrm{pH}$. Another study in the same country on vinasse from sugar beets [24] showed increased concentrations of soil organic matter and nitrogen and an increase in soil cation exchange capacity.

Studies in Greece [25] have described the effects of the addition of vinasse on the physicochemical properties of soils used for wheat production. The results indicated that the application of vinasse resulted in increased, but nontoxic, concentrations of potassium, sodium, and manganese in the soil. As a whole, it is possible to conclude that agricultural use of vinasse leads to improvements in soil quality with consequent benefits for crop productivity.

\section{Plant Response to Application of Vinasse}

The use of vinasse in fertigation systems has advantages because it can contribute substantial amounts of water and mineral nutrients, support soil quality and crop productivity [56], and finally, but no less importantly, can solve the environmental problem of the disposal of this agro-industrial residue.

In China sugar cane treated with vinasse has increased productivity and sucrose yields [26, 27]. In Brazil [19, 28], long-term application of vinasse $\left(150 \mathrm{~m}^{3} \mathrm{ha}^{-1}\right.$ year $\left.^{-1}\right)$ in sugar cane production confirmed positive effects on productivity and increased potassium concentration in soil, as already discussed. Other Brazilian studies [29] involving the application of vinasse and management of the straw cover in sugar cane production also indicated gains in productivity and sugar production. Applications of vinasse of $300-400 \mathrm{~m}^{3} \mathrm{ha}^{-1}$ were considered adequate to increase sugar and alcohol production [30]. In Greece, wheat production was increased by vinasse application, confirming the beneficial effects of the residue in agriculture. In Spain [24], yields of beets and maize were compared after treatments with an organic compound based on vinasse or a mineral fertilizer. Crop production was similar in both treatments indicating that the utilization of vinasse is a viable alternative for mineral fertilizers. Therefore, conservation practices, like the employment of residues in agriculture can contribute to increased agricultural productivity whilst minimizing environmental pollution. 


\section{Concluding Remarks}

Filter cake and vinasse, which are produced in large quantities by sugar-alcohol agroindustries in various countries, have great potential for agricultural use. Filter cake has been utilized with good results, as a substitute for phosphate mineral fertilizers in field crop production, in composting and vermicomposting processes, and as a substrate for the production of seedlings. The use of vinasse in fertigation is increasing in several agricultural areas, substituting for potassium mineral fertilizers and furnishing water, organic matter, and other mineral nutrients in smaller quantities. The use of both filter cake and vinasse should be optimized for each agricultural system and follow recommendations of responsible organisations to prevent environmental damage.

\section{References}

[1] R. P. Viator, R. M. Johnson, E. P. Richard Jr., H. L. Waguespack, and W. Jackson, "Influence of nonoptimal ripener applications and postharvest residue retention on sugarcane second ratoon yields," Agronomy Journal, vol. 100, no. 6, pp. 1769-1773, 2008.

[2] T. Goes, R. Marra, and G. S. Silva, "Setor sucroalcooleiro no Brasil situação atual e perspectivas," Revista Política Agrícola, vol. 17, no. 2, pp. 39-51, 2008.

[3] P. R. F. Fravet, R. A. B. Soares, R. M. Q. Lana, A. M. Q. Lana, and G. H. Korndörfer, "Efeito de doses de torta de filtro e modo de aplicação sobre a produtividade e qualidade tecnológica da soqueira de cana-de-açúcar," Ciência e Agrotecnologia, vol. 34, no. 3, pp. 618-624, 2010.

[4] D. H. Santos, M. A. Silva, C. S. Tiritan, J. S. S. Foloni, and F. R. Echer, "Qualidade tecnológica da cana-de-açúcar sob adubação com torta de filtro enriquecida com fosfato solúvel," Revista Brasileira de Engenharia Agrícola e Ambiental, vol. 15, no. 5, pp. 443-449, 2011.

[5] E. M. Ossom and R. L. Rhykerd, "Response of Ipomoea batatas (L.) Lam. to soil fertilization with filter cake," Transactions of the Illinois State Academy of Science, vol. 100, no. 3-4, pp. 197-208, 2007.

[6] E. M. Ossom, "Effects of filter cake fertilization on weed infestation, disease incidence and tuber yield of cassava (Manihot esculenta) in Swaziland," International Journal of Agriculture and Biology, vol. 12, no. 1, pp. 45-50, 2010.

[7] A. A. Abo-Baker Basha, "Improving filter mud cake with rock phosphate and biofertilizers for exporting organic onion production in newly cultivated land at south valley area," Australian Journal of Basic and Applied Sciences, vol. 5, no. 8, pp. 1354-1361, 2011.

[8] E. M. Ossom and F. T. Dlamini, "Effects of filter cake on soil mineral nutrients and maize (Zea mays L.) agronomy," Tropical Agriculture, vol. 89, no. 3, pp. 141-150, 2012.

[9] S. R. Utami, S. Kurniawan, B. Situmorang, and N. D. Rositasari, "Increasing P-availability and P-uptake using sugarcane filter cake and rice husk ash to improve chinesse cabbage (Brassica Sp) growth in Andisol, East Java," Journal of Agricultural Science, vol. 4, no. 10, pp. 153-160, 2012.

[10] C. T. C. Santana, A. Santi, R. Dallacort, M. L. Santos, and C. B. Menezes, "Desempenho de cultivares de alface americana em resposta a diferentes doses de torta de filtro," Revista Ciência Agronômica, vol. 43, no. 1, pp. 22-29, 2012.
[11] S. Meunchang, S. Panichsakpatana, and R. W. Weaver, "Cocomposting of filter cake and bagasse; by-products from a sugar mill," Bioresource Technology, vol. 96, no. 4, pp. 437-442, 2005.

[12] M. Khwairakpam and R. Bhargava, "Bioconversion of filter mud using vermicomposting employing two exotic and one local earthworm species," Bioresource Technology, vol. 100, no. 23, pp. 5846-5852, 2009.

[13] A. C. P. Santos, P. V. Baldotto, P. A. A. Marques, W. L. Domingues, and H. L. Pereira, "Utilização de torta de filtro como substrato para a produção de mudas de hortaliças," Colloquium Agrariae, vol. 1, no. 2, pp. 1-5, 2005.

[14] E. B. Azevedo, C. S. Marinho, R. A. Muniz, and A. J. C. Carvalho, "Substratos fertilizados com uréia revestida e o crescimento e estado nutricional da muda de citros," Acta Scientiarum. Agronomy, vol. 31, no. 1, pp. 129-137, 2009.

[15] A. J. N. Silva, M. S. V. Cabeda, F. G. Carvalho, and J. F. W. F. Lima, "Alterações físicas e químicas de um Argissolo amarelo sob diferentes sistemas de uso e manejo," Revista Brasileira de Engenharia Agrícola e Ambiental, vol. 10, no. 1, pp. 76-83, 2006.

[16] F. V. Bebé, M. M. Rolim, E. M. R. Pedrosa, G. B. Silva, and V. S. Oliveira, "Avaliação de solos sob diferentes períodos de aplicação com vinhaça," Revista Brasileira de Engenharia Agrícola e Ambiental, vol. 13, no. 6, pp. 781-787, 2009.

[17] R. P. B. Barros, P. R. A. Viégas, T. L. Silva et al., "Alterações em atributos químicos de solo cultivado com cana-de-açúcar e adição de vinhaça," Pesquisa Agropecuária Tropical, vol. 40, no. 3, pp. 341-346, 2010.

[18] F. L. Brito, M. M. Rolim, and E. M. R. Pedrosa, "Efeito da aplicação de vinhaça nas características químicas de solos da zona da mata de Pernambuco," Revista Brasileira de Ciências Agrárias, vol. 4, no. 4, pp. 456-462, 2009.

[19] C. A. Zolin, J. Paulino, A. Bertonha, P. S. L. Freitas, and M. V. Folegatti, "Estudo exploratório do uso da vinhaça ao longo do tempo. I. características do solo," Revista Brasileira de Engenharia Agrícola e Ambiental, vol. 15, no. 1, pp. 22-28, 2011.

[20] Z. P. Jiang, Y. R. Li, G. P. Wei et al., "Effect of long-term vinasse application on physico-chemical properties of sugarcane field soils," Sugar Tech, vol. 14, no. 4, pp. 412-417, 2012.

[21] Q. You, T. M. Su, and Y. Zhong, "Effects of vinasse on sugarcane field," Guangxi Agricultural Sciences, vol. 40, no. 6, pp. 677-680, 2009.

[22] Y. C. Meng, Q. Z. Tang, Z. Liu, G. F. Chen, and Y. Wang, "Impact of several organic materials of sugar industry on soil microbe population in sugarcane field," Southwest China Journal of Agricultural Sciences, vol. 22, no. 2, pp. 389-392, 2009.

[23] P. C. Bueno, J. A. M. Rubí, R. G. Giménez, and R. J. Ballesta, "Impacts caused by the addition of wine vinasse on some chemical and mineralogical properties of a Luvisol and a Vertisol in la Mancha (Central Spain)," Journal of Soils and Sediments, vol. 9, no. 2, pp. 121-128, 2009.

[24] E. Madejón, R. López, J. M. Murillo, and F. Cabrera, "Agricultural use of three (sugar-beet) vinasse composts: effect on crops and chemical properties of a Cambisol soil in the Guadalquivir river valley (SW Spain)," Agriculture, Ecosystems and Environment, vol. 84, no. 1, pp. 55-65, 2001.

[25] T. A. Gemtos, N. Chouliaras, and S. Marakis, "Vinasse rate, time of application and compaction effect on soil properties and durum wheat crop," Journal of Agricultural Engineering Research, vol. 73, no. 3, pp. 283-296, 1999. 
[26] Y. C. Mo, Y. P. Ye, Q. Liang, and Y. R. Li, "Effects of vinasse on the quality of sugarcane and key enzymes in sucrose synthesis," Southwest China Journal of Agricultural Sciences, vol. 22, no. 1, pp. 55-59, 2009.

[27] Y. R. Li, Q. Z. Zhu, and W. Z. Wang, "Multiple location experiment of technique system for direct rational application of vinasse from cane mill in sugarcane fields," Southwest China Journal of Agricultural Sciences, vol. 21, no. 3, pp. 749-756, 2008.

[28] J. Paulino, C. A. Zolin, A. Bertonha, P. S. L. Freitas, and M. V. Folegatti, "Estudo exploratório do uso da vinhaça ao longo do tempo. II. Características da cana-de-açúcar," Revista Brasileira de Engenharia Agrícola e Ambiental, vol. 15, no. 3, pp. 244-249, 2011.

[29] A. S. Resende, A. Santos, R. P. Xavier et al., "Efeito da queima da palhada da cana-de-açúcar e de aplicações de vinhaça e adubo nitrogenado em características tecnológicas da cultura," Revista Brasileira de Ciência do Solo, vol. 30, no. 6, pp. 937-941, 2006.

[30] A. F. Paulino, C. C. Medina, C. R. P. Robaina, and R. A. Laurani, "Produções agrícola e industrial de cana-de-açúcar submetida a doses de vinhaça," Semina: Ciências Agrárias, vol. 23, no. 2, pp. 145-150, 2002.

[31] G. E. Rayment, "Northeast Australian experience in minimizing environmental harm from waste recycling and potential pollutants of soil and water," Communications in Soil Science and Plant Analysis, vol. 36, no. 1-3, pp. 121-131, 2005.

[32] R. F. B. Vasconcelos, J. R. B. Cantalice, A. J. N. Silva, V. S. Oliveira, and Y. J. A. B. Silva, "Limites de consistência e propriedades químicas de um Latossolo Amarelo distrocoeso sob aplicação de diferentes resíduos da cana-de-açúcar," Revista Brasileira de Ciência do Solo, vol. 34, no. 3, pp. 639-648, 2010.

[33] R. Rossetto, F. L. F. Dias, A. C. Vitti, H. Cantarella, and M. G. A. Landell, "Manejo conservacionista e reciclagem de nutrientes em cana-de-açúcar tendo em vista a colheita mecânica," Informações Agronômicas, no. 124, pp. 8-13, 2008.

[34] B. van Raij and H. Cantarella, "Outras culturas industriais," in Recomendações de adubação e calagem para o estado de São Paulo, B. van Raij, H. Cantarella, J. A. Quaggio, and A. M. C. Furlani, Eds., Boletim técnico 100, pp. 233-239, Instituto Agronômico, Campinas, Brazil, 2nd edition, 1997.

[35] G. H. Korndörfer and S. P. Melo, "Fontes de fósforo (fluida ou sólida) na produtividade agrícola e industrial da cana-deaçúcar," Ciência e Agrotecnologia, vol. 33, no. 1, pp. 92-97, 2009.

[36] O. A. Camargo, R. S. Berton, R. N. Geraldi, and J. M. A. S. Valadares, "Alterações de características químicas de um Latossolo Roxo distrófico incubado com resíduos da indústria álcool-açucareira," Bragantia, vol. 43, no. 1, pp. 125-139, 1984.

[37] G. H. Korndörfer and D. L. Anderson, "Use and impact of sugaralcohol residues vinasse and filter on sugarcane production in Brazil," Sugar y Azucar, vol. 92, no. 3, pp. 26-35, 1997.

[38] B. Díaz, B. Barreto, P. Cairo et al., "La aplicación de fertilizantes orgánicos y minerales naturales en el cultivo de la caña de azúcar (parte II): efecto a largo plazo sobre el rendimiento y la calidad del suelo," Centro Azúcar, vol. 37, no. 1, pp. 35-42, 2010.

[39] E. M. Ossom and M. H. Nxumalo, "Effects of filter cake on agronomic characteristics and yield of maize (Zea mays L.) in Swaziland," UNISWA Journal of Agriculture, vol. 14, no. 1, pp. 81-89, 2006.

[40] N. P. S. Yaduvanshi, D. V. Yadav, and T. Singh, "Economy in fertilizer nitrogen by its integrated application with sulphitation filter cake on sugarcane," Biological Wastes, vol. 32, no. 1, pp. 7579, 1990.
[41] M. T. Elsayed, M. H. Babiker, M. E. Abdelmalik, O. N. Mukhtar, and D. Montange, "Impact of filter mud applications on the germination of sugarcane and small-seeded plants and on soil and sugarcane nitrogen contents," Bioresource Technology, vol. 99, no. 10, pp. 4164-4168, 2008.

[42] A. B. A. Júnior, C. W. A. Nascimento, M. F. Sobral, F. B. V. Silva, and W. A. Gomes, "Fertilidade do solo e absorção de nutrientes em cana-de-açúcar fertilizada com torta de filtro," Revista Brasileira de Engenharia Agrícola e Ambiental, vol. 15, no. 10, pp. 1004-1001, 2011.

[43] W. T. Tsai, H. P. Chen, C. W. Lai, K. J. Hsien, M. S. Lee, and J. M. Yang, "Preparation of adsorbents from sugarcane manufacturing by-product filter-mud by thermal activation," Journal of Analytical and Applied Pyrolysis, vol. 70, no. 2, pp. 399-411, 2003.

[44] B. Sen and T. S. Chandra, "Chemolytic and solid-state spectroscopic evaluation of organic matter transformation during vermicomposting of sugar industry wastes," Bioresource Technology, vol. 98, no. 8, pp. 1680-1683, 2007.

[45] T. A. Butler, L. J. Sikora, P. M. Steinhilber, and L. W. Douglass, "Compost age and sample storage effects on maturity indicators of biosolids compost," Journal of Environmental Quality, vol. 30, no. 6, pp. 2141-2148, 2001.

[46] P. Sangwan, C. P. Kaushik, and V. K. Garg, "Feasibility of utilization of horse dung spiked filter cake in vermicomposters using exotic earthworm Eisenia foetida," Bioresource Technology, vol. 99, no. 7, pp. 2442-2448, 2008.

[47] T. A. S. Freitas, D. G. Barroso, J. G. A. Carneiro, R. M. Panchel, K. R. Lamônica, and D. A. Ferreira, "Desempenho radicular de mudas de eucalipto produzidas em diferentes recipientes e substratos," Revista Árvore, vol. 29, no. 6, pp. 853-861, 2005.

[48] M. A. S. Silva, N. P. Griebeler, and L. C. Borges, "Uso de vinhaça e impactos nas propriedades do solo e lençol freático," Revista Brasileira de Engenharia Agrícola e Ambiental, vol. 11, no. 1, pp. 108-114, 2007.

[49] E. M. O. Laime, P. D. Fernandes, D. C. S. Oliveira, and E. A. Freire, "Possibilidades tecnológicas para a destinação da vinhaça: uma revisão," Revista Trópica, vol. 5, no. 3, p. 16, 2011.

[50] M. R. C. C. Lyra, M. M. Rolim, and J. A. A. Silva, “Toposseqüência de solos fertigados com vinhaça: contribuição para a qualidade das águas do lençol freático," Revista Brasileira de Engenharia Agrícola e Ambiental, vol. 7, no. 3, pp. 525-532, 2003.

[51] F. L. Brito, M. M. Rolim, and E. M. R. Pedrosa, "Concentração de cátions presentes no lixiviado de solos tratados com vinhaça," Engenharia Agrícola, vol. 27, no. 3, pp. 773-781, 2007.

[52] F. B. Zúñiga, M. C. D. Bazúa, and R. Lozano, “Cambios químicos en el suelo por aplicación de materia orgánica soluble tipo vinazas," Revista Internacional de Contaminación Ambiental, vol. 16, no. 3, pp. 89-101, 2000.

[53] V. Z. Cerón and M. A. G. Ayerbe, “Caracterización ambiental de las vinazas de residuos de caña de azúcar resultantes de la producción de etanol," Dyna, vol. 80, no. 177, pp. 124-131, 2013.

[54] J. F. G. P. Ramalho and N. M. B. A. Sobrinho, "Metais pesados em solos cultivados com cana-de-açúcar pelo uso de resíduos agroindustriais," Floresta e Ambiente, vol. 8, no. 1, pp. 120-129, 2001. 
[55] F. L. Brito, M. M. Rolim, J. A. A. Silva, and E. M. R. Pedrosa, "Qualidade do percolado de solos que receberam vinhaça em diferentes doses e tempo de incubação," Revista Brasileira de Engenharia Agrícola e Ambiental, vol. 11, no. 3, pp. 318-323, 2007.

[56] C. Á. R. Junqueira, V. E. Molina Jr., L. F. Lossardo et al., "Identificação do potencial de contaminação de aquíferos livres por vinhaça na bacia do Ribeirão do Pântano, Descalvado (SP), Brasil," Revista Brasileira de Geociências, vol. 39, no. 3, pp. 507518, 2009. 

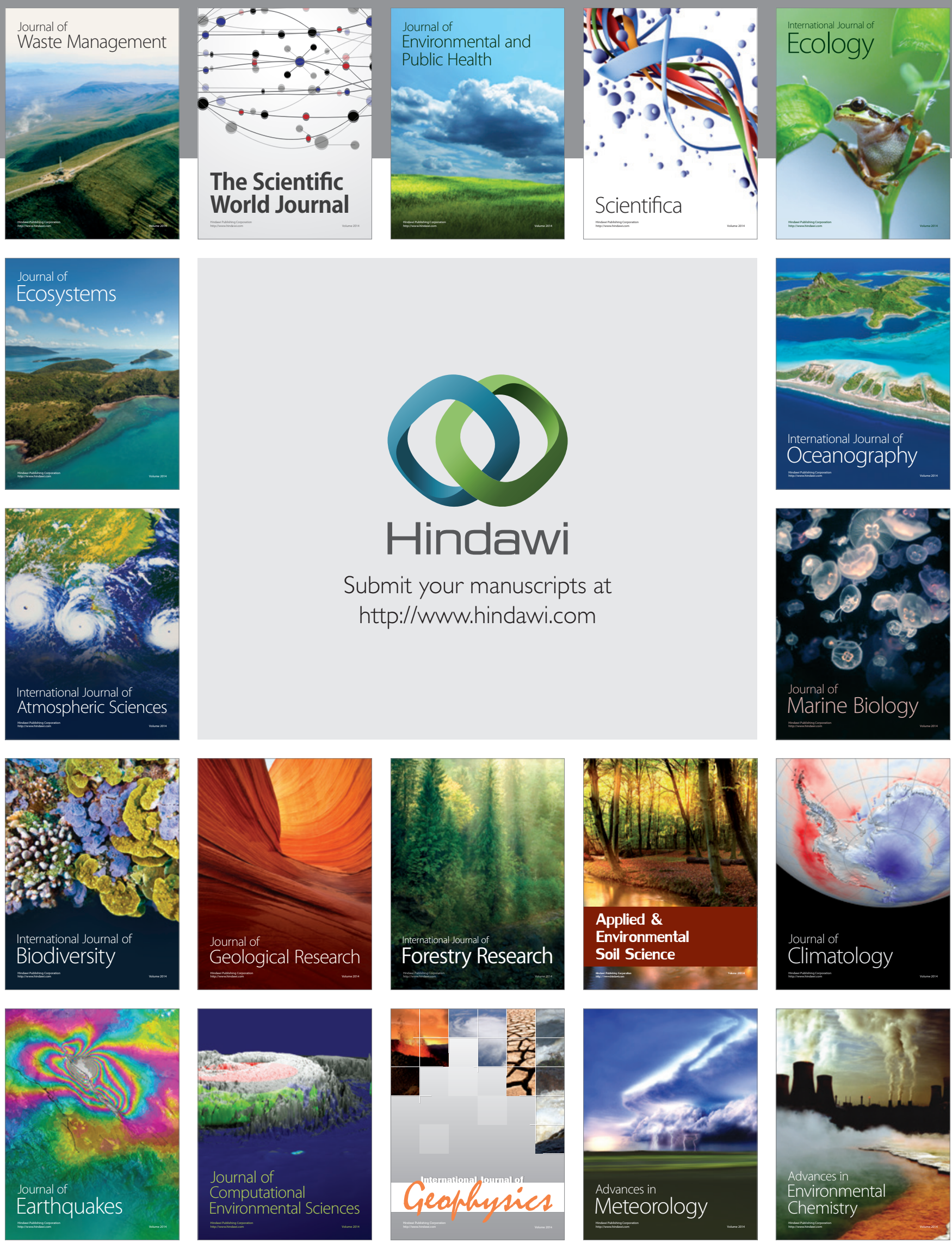